\title{
Polyphasic Characterization of Xanthomonas axonopodis pv. allii Associated with Outbreaks of Bacterial Blight on Three Allium Species in the Mascarene Archipelago
}

\author{
Y. Picard, P. Roumagnac, D. Legrand, L. Humeau, I. Robène-Soustrade, \\ F. Chiroleu, L. Gagnevin, and O. Pruvost
}

CIRAD, UMR Peuplements Végétaux et Bioagresseurs en Milieu Tropical CIRAD-Université de la Réunion, Pôle de Protection des Plantes,

7, chemin de l'Irat, 97410 Saint Pierre, La Réunion, France.

Current address of second author: Laboratoire d'Écologie Microbienne de la Rhizosphère et des environnements Extrêmes (LEMIRE), UMR

6191 CNRS-CEA-Aix Marseille Univ, 13108 Saint-Paul-lez-Durance, France.

Accepted for publication 15 April 2008.

\section{ABSTRACT}

Picard, Y., Roumagnac, P., Legrand, D., Humeau, L., Robène-Soustrade, I., Chiroleu, F., Gagnevin, L., and Pruvost, O. 2008. Polyphasic characterization of Xanthomonas axonopodis pv. allii associated with outbreaks of bacterial blight on three Allium species in the Mascarene archipelago. Phytopathology 98:919-925.

Based on the number of new reports during the last two decades, bacterial blight of onion (Allium cepa) is considered an emerging disease. The causal agent, Xanthomonas axonopodis pv. allii, is pathogenic to several Allium species after inoculation, but outbreaks worldwide have been primarily reported on onion. We describe a unique epidemiological situation in Réunion Island, France, with concomitant outbreaks on three Allium species, onion, leek (A. porrum), and garlic (A. sativum). There was no host specialization within Allium spp. among strains associated with the three host species. Based on amplified fragment length polymorphism (AFLP) and restriction fragment length polymorphism, strains associated with these outbreaks in Réunion Island were highly related genetically to strains isolated from diseased plant samples and contaminated seed lots in the neighboring island of Mauritius, where the disease has occurred since 1984. All AFLP haplotypes were identified as $X$. axonopodis pv. allii based on polymerase chain reaction analysis using specific primers, biochemical tests, and/or pathogenicity tests. Two genetically related groups of strains (A and B) that can be distinguished by AFLP, differential utilization of three carbon sources, and xanthomonadin pigment production were detected initially after establishment of the pathogen. In less than 10 years after the establishment of the pathogen there was nearly an extinction of group A strains in Réunion Island, suggesting differences in fitness between strains in the two groups.

Additional keywords: emerging pathogen, in planta growth rates, seed transmission.
Since the original description of the disease and its causal agent in Hawaii (2), bacterial blight of onion (Allium cepa L.) (BBO) has been reported from many countries worldwide, with an increasing number of disease reports since then (26). Consequently, the causal agent, Xanthomonas axonopodis pv. allii (26) (synonym $X$. campestris pv. allii [19]), is an emerging pathogen and was recently included on the alert list of the European and Mediterranean Plant Protection Organization (EPPO). In the Mascarene archipelago (South West Indian Ocean), BBO was first recorded in Mauritius in 1984 (S. Benimadhu, personal communication), and subsequently in the neighboring Réunion Island, where the disease was first observed in onion fields in 1993. After 2000, major outbreaks were also reported in Réunion on leek and garlic.

$X$. axonopodis pv. allii is pathogenic after inoculation on several Allium species including onion, garlic (A. sativum L.), leek (A. porrum L.), and Welsh onion (A. fistulosum L.) (26). On onion, lesions consist of lenticular water-soaked leaf spots which turn into dry chlorotic lesions that eventually coalesce. When

Corresponding author: O. Pruvost; E-mail address: olivier.pruvost@cirad.fr

* The $\boldsymbol{e}$-Xtra logo stands for "electronic extra" and indicates that the online version contains two tables showing the geographic origins and other characteristics of the 279 strains of $X$. axonopodis pv. allii used in this study.

doi:10.1094/PHYTO-98-8-0919

(C) 2008 The American Phytopathological Society disease is severe, leaf dieback can occur, resulting in a reduction of bulb size. The morphology of leaf lesions on other Allium species is similar to those on onion (26). X. axonopodis pv. allii was also pathogenic to citrus after bacterial infiltration, and produced lesions that were similar to citrus bacterial spot (12). There is no experimental evidence of strains of this bacterium being pathogenic to citrus under field conditions.

Amplified fragment length polymorphism (AFLP), a technique widely used for studying the epidemiology of human bacterial pathogens $(8,9,15,21,25,31)$, successfully distinguished local inoculum from inoculum resulting from migration events in epidemiological studies of the BBO pathosystem (17). In this study, we describe a polyphasic characterization (including AFLP and restriction fragment length polymorphism [RFLP] analyses, polymerase chain reaction [PCR] amplification with specific primers, biochemical and physiological assays, and pathogenicity tests) of $X$. axonopodis pv. allii strains originating from the Mascarene archipelago (Réunion and Mauritius Islands). The objectives of this study were to evaluate the relatedness between strains of $X$. axonopodis pv. allii from Réunion and Mauritius Islands, and to examine genetic and pathological variations among strains from BBO outbreaks recorded in Réunion Island on onion, garlic, and leek.

\section{MATERIALS AND METHODS}

Bacterial strains and generic media. The $X$. axonopodis pv. allii strains used in this study included 19 strains from diseased 
onion collected from 1996 to 2000 in Mauritius, 15 strains from onion seeds harvested in 1996 in Mauritius, 158 strains from onion collected from 1993 to 2005 in Réunion Island, two strains from a single diseased garlic plant collected in 1994 in Réunion Island, 30 strains from diseased garlic collected from 2001 to 2004 in Réunion Island, 46 strains from diseased leek collected from 2001 to 2005 in Réunion Island, and nine $X$. axonopodis pv. allii strains from other regions: Brazil (CFBP 6362, 6363, 6377, 6378, and JVJ93), Barbados (CFBP 6367 and 6368), and Japan (CFBP $6107^{\mathrm{PT}}$ and 6108) (Collection Française de Bactéries Phytopathogènes, INRA Angers, France). Strains were stored at $-80^{\circ} \mathrm{C}$ on beads in cryovials (Microbank Prolab Diagnostics, Austin, TX) and/or as lyophiles. Bacteria were cultured on yeast peptone glucose agar (YPGA; yeast extract $7 \mathrm{~g}$ liter $^{-1}$, peptone $7 \mathrm{~g}$ liter ${ }^{-1}$, glucose $7 \mathrm{~g} \mathrm{liter}^{-1}$, agar $18 \mathrm{~g} \mathrm{liter}^{-1}, \mathrm{pH} 7.2$ ).

AFLP analysis. A total of 225 strains were analyzed by AFLP. For each strain, at least two independent DNA extractions obtained from a single bacterial colony were used for AFLP analyses. AFLP was performed as described previously (1). Briefly, DNA was digested with SacI and MspI (New England Biolabs Ozyme, Saint Quentin Yvelines, France), as recommended by the manufacturer. Then, $2.5 \mu \mathrm{l}$ of the digested products was added to $22.5 \mu \mathrm{l}$ of a ligation mix containing $2 \mu \mathrm{M} \mathrm{MspI}$ adaptor, $0.2 \mu \mathrm{M}$ SacI adaptor (Applied Biosystems, Courtaboeuf, France), and $2 \mathrm{U}$ of T4 DNA ligase (New England Biolabs Ozyme) in $1 \times$ T4 DNA ligation buffer. Ligations were performed for $3 \mathrm{~h}$ at $37^{\circ} \mathrm{C}$ before enzyme inactivation at $65^{\circ} \mathrm{C}$ for $10 \mathrm{~min}$. Ligation products were diluted 10-fold with high-performance liquid chromatography (HPLC)-grade water before preselective PCR. The reactions were done in $15 \mu \mathrm{l}$ and contained $5 \mu \mathrm{l}$ of diluted ligation product, $2.5 \mathrm{mM} \mathrm{MgCl} 2,0.23 \mu \mathrm{M}$ of each MspI and $S a c \mathrm{I}$ primer, $0.45 \mathrm{mM}$ of each dNTP (New England Biolabs Ozyme), $0.5 \mathrm{U}$ of Taq DNA polymerase (Goldstar Red, Eurogentec, Seraing, Belgium), in 1× Goldstar buffer. The following PCR conditions were used: initial extension to ligate the second strand of the adaptors at $72^{\circ} \mathrm{C}$ for $2 \mathrm{~min}$, a denaturation step at $94^{\circ} \mathrm{C}$ for $2 \mathrm{~min}, 25$ cycles at $94^{\circ} \mathrm{C}$ for $30 \mathrm{~s}, 56^{\circ} \mathrm{C}$ for $30 \mathrm{~s}$, and $72^{\circ} \mathrm{C}$ for $2 \mathrm{~min}$, and a final extension step at $72^{\circ} \mathrm{C}$ for $10 \mathrm{~min}$. PCR products were diluted 10 -fold with HPLC-grade water before selective amplification. The selectiveamplifications using the unlabeled $M s p \mathrm{I}+\mathrm{A}, \mathrm{C}, \mathrm{T}$, or $\mathrm{G}$ primer and the labeled SacI+C primer (four different fluorochromes) were performed in the same conditions as the preselective PCR except that the $\mathrm{Sac}+\mathrm{C}$ primer concentration was $0.12 \mu \mathrm{M}$. The following PCR conditions were used during selective amplifications: initial denaturation at $94^{\circ} \mathrm{C}$ for 2 min followed by 37 cycles at $94^{\circ} \mathrm{C}$ for $30 \mathrm{~s}$, annealing for $30 \mathrm{~s}$ at $65^{\circ} \mathrm{C}$ for the first cycle, decreased by $0.7^{\circ} \mathrm{C}$ per cycle for the next 12 cycles, and then $56^{\circ} \mathrm{C}$ for the last 24 cycles, and extension at $72^{\circ} \mathrm{C}$ for 2 min with a final extension step at $72^{\circ} \mathrm{C}$ for $10 \mathrm{~min}$. Samples were then prepared for capillary electrophoresis by adding $1 \mu \mathrm{l}$ of the final PCR product to $18.7 \mu \mathrm{l}$ of formamide and $0.3 \mu \mathrm{l}$ of LIZ500 DNA ladder (Applied Biosystems) as an internal standard. The mixture was then denatured for $5 \mathrm{~min}$ at $95^{\circ} \mathrm{C}$ and placed on ice for at least $5 \mathrm{~min}$. Electrophoresis was performed in an ABI PRISM3100 Genetic Analyzer (Applied Biosystems) using performance optimized polymer POP-4 at $15,000 \mathrm{~V}$ for about $20 \mathrm{~min}$ at $60^{\circ} \mathrm{C}$, with an initial injection of $66 \mathrm{~s}$. The AFLP fingerprints were analyzed visually using Genescan software 3.7 (Applied Biosystems). Strain CFBP 6369 was used as a control in each experiment.

The presence or absence of reproducible DNA fragments obtained with the four combinations was scored in a binary matrix. A neighbor-joining tree (11) with bootstrap values (1,000 repeated samplings) was constructed based on the Dice dissimilarity coefficient using DARwin 5.0 software (CIRAD, Montpellier, France).

Physiological, biochemical tests, and carbon source utilization assay. A subset of 106 strains representative of the genetic diversity based on AFLP analysis were used for physiological, biochemical, and carbon source utilization tests. Physiological and biochemical tests used included Gram test, O/F glucose metabolism, oxidase, urease, indole production, production of fluorescent pigments, starch hydrolysis, gelatin hydrolysis, esculin hydrolysis, milk proteolysis, cellulose hydrolysis, Tween esterase, $\mathrm{H}_{2} \mathrm{~S}$ production from cysteine, and pectolytic activity. Physiological and biochemical tests were conducted as described by Vernière et al. (32) except for pectolytic activity (14) and gelatin hydrolysis (20). Carbon source utilization patterns were determined as described previously (26) using the Biolog GN system (Biolog Inc., Hayward, CA) (4).

Absorption spectrum of xanthomonadin pigment. Because two colony color types (bright yellow and pale yellow) were observed visually within the strain collection, the xanthomonadin pigments from a subset of nine strains were analyzed. Methanol extraction of xanthomonadin was slightly modified from Schaad (30). Bacterial cells obtained from 48-h-old cultures on nutrient agar ( $3 \mathrm{~g}$ of meat extract, $5 \mathrm{~g}$ of bactopeptone, $15 \mathrm{~g}$ of agar, and $1,000 \mathrm{ml}$ of distilled water, $\mathrm{pH} 7.3)$ were centrifuged $(4,500 \mathrm{rpm}$ for $5 \mathrm{~min}$ ) in $0.01 \mathrm{M}$ sterile Sigma 7 to 9 buffer (Sigma Aldrich, Saint-Quentin Fallavier, France) $\mathrm{pH}$ 7.2. This washing step was repeated eight times until a clear supernatant was obtained. Bacterial suspensions were adjusted spectrophotometrically $\left(\mathrm{OD}_{600}\right.$ of 100 -fold-diluted suspensions $=0.04$ ) to contain approximately $8 \times 10^{9} \mathrm{CFU} \mathrm{ml}{ }^{-1}$. Bacterial pellets were allowed to dry overnight at room temperature and were then suspended in $5 \mathrm{ml}$ of methanol. Tubes were then placed in boiling water for $1 \mathrm{~min}$. After centrifugation of the suspensions, supernatants were saved in new tubes. The absorption spectra of the xanthomonadin extracts were measured spectrophotometrically (Hewlett Packard spectrophotometer HP8453, Les Ulis, France) between 250 and $600 \mathrm{~nm}$.

PCR amplification with PXaa1 and NXaa1 primers. Genomic DNAs from 129 strains were used for PCR. Template consisted of $1 \mu \mathrm{l}$ of bacterial suspension boiled for $1 \mathrm{~min}$ and chilled on ice. Suspensions were prepared from 24-h-old cultures grown on YPGA in HPLC grade water and contained approximately $1 \times$ $10^{8} \mathrm{CFU} \mathrm{m}{ }^{-1}$. PCR reactions were performed as described previously (17). The first round of PCR was performed with primers PXaa1U (5'-GGCTCTAATACGACGTTGACGAT-3') and Pxaa1L (5'-AAATTCATGCGCGTTTTCAATAG-3'), which complement bases 197 to 219 and bases 871 to 893, respectively, of a sequence-characterized amplified region (SCAR) specific to $X$. axonopodis pv. allii strains. The amplification program included initial denaturation at $94^{\circ} \mathrm{C}$ for $5 \mathrm{~min}, 40$ cycles consisting of denaturation at $95^{\circ} \mathrm{C}$ for $1 \mathrm{~min}$, annealing at $68^{\circ} \mathrm{C}$ for $1 \mathrm{~min}$ and extension at $72^{\circ} \mathrm{C}$ for $2 \mathrm{~min}$, and a final extension step at $72^{\circ} \mathrm{C}$ for 5 min. Strains negative with PXaal primers were further evaluated using internal primers. The primers used in the second PCR round were NxaaU1 (5'-TTACGTCGCAAACAATCCAGATA-3') and NxaaL1 (5'-GGGCACCATTGACATTATCAGTT$3^{\prime}$ ), which complement bases 424 to 446 and 848 to 870 of the SCAR sequence, respectively. For this second round of PCR, $1 \mu \mathrm{l}$ from the first reaction was used as template and the amplification program consisted of denaturation at $94^{\circ} \mathrm{C}$ for $5 \mathrm{~min}$, followed by 30 cycles of $94^{\circ} \mathrm{C}$ for $30 \mathrm{~s}, 68^{\circ} \mathrm{C}$ for $30 \mathrm{~s}, 72^{\circ} \mathrm{C}$ for $40 \mathrm{~s}$, and a final extension at $72^{\circ} \mathrm{C}$ for $5 \mathrm{~min}$. PCRs were performed in $25 \mu \mathrm{l}$ reaction mixtures containing $3 \mathrm{mM} \mathrm{MgCl}, 100 \mu \mathrm{M}$ of each dNTP, $0.2 \mu \mathrm{M}$ of each primer (PXaa1U/Pxaa1L or NxaaU1/ NxaaL1), $1 \mu$ l template DNA and $1.25 \mathrm{U}$ Taq polymerase Goldstar Red (Eurogentec) in $75 \mathrm{mM}$ Tris- $\mathrm{HCl}, 20 \mathrm{mM}\left(\mathrm{NH}_{4}\right)_{2} \mathrm{SO}_{4}$, $0.01 \%$ Tween 20 buffer ( $\mathrm{pH}$ 8.8). Negative controls in which water was used as template were included in all experiments. PCR reaction products were separated by electrophoresis in $1 \%$ Seakem LE agarose (FMC Bioproducts, Philadelphia, PA), stained with ethidium bromide, and visualized with UV light. Because nested PCR is known to sometimes produce false positives, only samples from which the expected DNA fragment was detected at least twice were scored as positive. 
Restriction fragment length polymorphism (RFLP) analysis. Genomic DNAs from 115 strains representative of the genetic diversity based on AFLP were extracted by the CTAB method (3). DNAs were digested to completion with NgoMIV (New England Biolabs) or EcoRI (New England Biolabs). Digested-DNA fragments were separated in a $1 \%$ agarose gel $(25-\mathrm{cm}$ long) by electrophoresis at $50 \mathrm{~V}$ for $20 \mathrm{~h}(E c o R I)$ or $26 \mathrm{~h}(\mathrm{NgoMIV})$ in TAE buffer, and gel blotting was performed as described previously (10). Southern blots with NgoMIV-digested DNA were hybridized with the labeled 16S-ITS1-23S rDNA fragment. The rDNA fragment used as probe was prepared by PCR amplification from strain CFBP 6369 (Collection Française de Bactéries Phytopathogènes, Beaucouzé, France). Primer FGPS6 (5'-GGAGAGTTAGATCTTGGCTCAG-3') and 23S4675 (5'-CACTCCGGTCCTCTCGTA- $3^{\prime}$ ) were used, and are located at the beginning of the $16 \mathrm{~S}$ rRNA gene (22) and at the end of the 23S rRNA gene, respectively. Primer 23S4675 was designed using OLIGO 5.0 (National BioSciences Inc., Plymouth MN) from rDNA operon sequences of $X$. citri pv. citri (6). Primers were synthesized by SigmaGenosys (Cambridge, UK). PCR reactions were performed in a $100-\mu \mathrm{l}$ volume containing $10 \mathrm{ng}$ of template DNA, $10 \mathrm{U}$ of a mixture of Taq, and Tgo DNA polymerases (Expand Long Template PCR System, Roche Diagnostics, Meylan, France), 1× reaction buffer 3 (supplied by the manufacturer with the polymerase), $0.4 \mu \mathrm{M}$ of each primer, $40 \mu \mathrm{M}$ of each dNTP (Roche Diagnostics, Meylan, France), and HPLC grade water (SigmaAldrich, Saint-Quentin Fallavier, France). The amplification consisted of a 3 min denaturation step at $95^{\circ} \mathrm{C}$, followed by 30 cycles of DNA denaturation step at $95^{\circ} \mathrm{C}$ for $1 \mathrm{~min}, 1 \mathrm{~min}$ annealing at $60^{\circ} \mathrm{C}$, and $5 \mathrm{~min}$ extension at $72^{\circ} \mathrm{C}$. A final extension step was performed at $72^{\circ} \mathrm{C}$ for $15 \mathrm{~min}$. PCRs were performed using a PE9600 thermocycler (Applied Biosystems, Courtaboeuf, France). Blots with EcoRI-digested DNA were hybridized with the labeled plasmid pXV9 (extracted and purified using the plasmid midi kit (Qiagen, Courtaboeuf, France) containing an approximately 25-kb hrp cluster from $X$. axonopodis pv. vesicatoria (5). Probe labeling, hybridization, and detection were performed with the kit ECL as described by the manufacturer (GE Healthcare, Saclay, France) under high stringency conditions.

Pathogenicity tests. At least five strains per AFLP haplotype (when available) were inoculated on the host species from which they originated. Six strains (three from each AFLP group) originating from the intercepted seed lot also were checked for pathogenicity on onion cv. Red Creole. In addition, a subset of 28 strains (5 strains identified as AFLP group A, 18 strains identified as AFLP group B, strain LMG 16528, and 4 strains from other countries) were checked for pathogenicity on three host species (onion cv. Red Creole, garlic cv. Vacoa, and leek cv. Gros Long d'Été). Spray-inoculations of bacterial suspensions containing approximately $1 \times 10^{7}$ and $1 \times 10^{4} \mathrm{CFU} \mathrm{ml}^{-1}$ and subsequent analyses were performed as described previously (27). Briefly, $200 \mathrm{ml}$ of bacterial suspension prepared in $0.01 \mathrm{M}$ sterile Sigma 7 to 9 buffer ( $\mathrm{pH}$ 7.2) was sprayed on $10 \mathrm{cv}$. Red Creole onion plants at the 4 to 5 leaf stage. In each experiment, a negative control (buffer inoculation) and a positive control (CFBP 6366 and/or JQ632-1) were used. Inoculated plants were incubated in growth chambers at $30 \pm 1^{\circ} \mathrm{C}$ day, $26 \pm 1^{\circ} \mathrm{C}$ night, $95 \%$ relative humidity $(\mathrm{RH})$ and a 12-h photoperiod with a light intensity of approximately $390,000 \mathrm{~lm}$. Disease ratings were recorded up to 12 days after inoculation (dai). Disease scores were the sum of BBO leaf lesions observed on the 10 inoculated plants 8 dai. The pathogen was re-isolated from up to 15 leaf lesions per strainhost combination using NCTM1 semi-selective medium as previously reported (27). All experiments were replicated at least once.

In planta multiplication in detached onion leaves. Nine strains originating from Réunion Island were used for this study. They included two strains from onion identified as AFLP group A, the unique AFLP haplotype LMG 16528, and six strains identified as AFLP group B (two from onion, two from leek, and two from garlic). As BBO lesions induce a quick lodging and decay of onion leaves, we developed a detached leaf assay for measuring in planta multiplication over time of $X$. axonopodis pv. allii. Onion leaves (cv. Véronique) were surface disinfested with $1 \% \mathrm{NaOCl}$ and cut into approximately 5 -cm-long fragments. Leaf fragments were placed on the surface of water agar $\left(10 \mathrm{~g} \mathrm{liter}^{-1}\right)$ supplemented with benlate at $50 \mathrm{mg} \mathrm{ml}^{-1}$. Bacterial suspensions prepared in $0.01 \mathrm{M}$ sterile Sigma 7 to 9 Tris buffer (pH 7.2) and containing approximately $1 \times 10^{4}$ cells ml-1 were obtained from serial dilutions of suspensions adjusted spectrophotometrically $\left(\mathrm{OD}_{600}=0.05\right)$ to contain approximately $1 \times 10^{8} \mathrm{CFU} \mathrm{ml}{ }^{-1}$. For inoculation, a $10 \mu \mathrm{l}$ droplet of inoculum was deposited on a single wound made in the center of each fragment using a sterile needle. Plates were sealed with Parafilm, and were incubated for 6 days at $26 \pm 1{ }^{\circ} \mathrm{C}$ and a 12-h photoperiod with a light intensity of approximately 40,000 $\mathrm{lm}$. Each day, eight fragments per strain were used for population size determination. For this, fragments were individually processed using a stomacher device (Seward Medical, London, UK) at high speed for $30 \mathrm{~s}$ in $20 \mathrm{ml}$ of $0.01 \mathrm{M}$ sterile Sigma 7 to 9 buffer (pH 7.2). Appropriate dilutions were plated on semi-selective NCTM1 medium as described previously (27). Experiments were replicated once.

The fit of the log-transformed bacterial population data to a normal distribution was examined and variances homogeneity was checked with the Bartlett test. Nonlinear exponential, Gompertz, complementary log-log, logistic, and probit models were fitted to the data, and parameters were estimated for each bacterial strain using R software (version 2.6.0; R Development Core Team, Vienna, Austria). The appropriateness of each model was assessed by visual examination of the residual plots, correlation analysis of observed versus predicted values, and the use of the Akaike information criterion (7). For the model which was most suitable overall, a comparison of two of the three parameters (the daily multiplication rate $\mathrm{r}^{*}$ and the maximum population size $K)$ was performed using a maximum likelihood ratio test $(P=$ 0.05 ). Confidence intervals for the model parameters were estimated by the bootstrap method (16).

\section{RESULTS}

AFLP analysis. The overall AFLP data set was composed of 183 markers, 16 (8.7\%) of which were monomorphic. All strains originating from the Mascarene archipelago clearly differed from $X$. axonopodis pv. allii strains from other countries (Fig. 1). The tree representation separated strains originating from the Mascarene archipelago into two major groups supported by bootstrap values $\geq 97 \%$. Group A strains were characterized by four unique markers (i.e., markers that are present in all group A genomes and absent in all group B genomes), whereas group B strains were characterized by eight unique markers. When compared pairwise, any group A and B pair of strains differed by 20 to 30 markers. Both groups contained strains from both countries that were isolated from diseased onion leaves, scapes, and contaminated seed. Group A contained six haplotypes that differed by one to four markers. This group contained only strains producing pale yellow colonies on agar media $(n=35)$ that were isolated from onion diseased plants and seed in 1998 or earlier. Group B contained nine haplotypes that differed by one to six markers. This group contained only strains producing bright yellow colonies on agar media $(n=179)$ collected from diseased onion, garlic, and leek and onion seed from 1993 to 2005. Only a single strain isolated from diseased onion in Réunion Island (i.e., LMG 16528) did not cluster within A and B groups.

Physiological, biochemical tests, and carbon source utilization assay. Biochemical and physiological tests did not reveal variability among strains originating from diseased plant material. The biochemical and physiological properties of the strains were 
characteristic of the genus Xanthomonas. These strains hydrolyzed starch, gelatin, casein, and had pectolytic activity at $\mathrm{pH}$ 5.0, 7.0, and 8.5.

Carbon source utilization varied among strains originating from the Mascarene archipelago. All strains producing pale yellow colonies and identified as AFLP group A utilized L-fucose, Dmelibiose, and citric acid, in contrast to strains identified as AFLP group B. Strain LMG 16528, which was identified as a unique haplotype by AFLP and produced bright yellow colonies on agar media, also utilized L-fucose, D-melibiose, and citric acid. Among strains from other genetic groups, strains from Barbados and two strains from Brazil (CFBP 6362 and 6378) utilized all three carbon sources. Strains originating from Japan utilized Dmelibiose and citric acid. The three remaining strains from Brazil utilized L-fucose and D-melibiose.

Absorption spectrum of xanthomonadin pigment. The maximal absorption of the pigment extracts ranged from 440 to $445 \mathrm{~nm}$. The absorption values observed for pale yellow cultures (AFLP group A) was approximately half of those observed for bright yellow cultures (AFLP group B), therefore confirming the visual observations made on YPGA plates.

RFLP analysis. Five and four different hybridization profiles were identified based on RFLP using the hrp and rDNA probes, respectively. All strains from Réunion and Mauritius Islands were of a single $h r p$ ( $h r p-1)$ and rDNA profile (rDNA-1). Strains from other countries were distinguishable from those using either probe (Fig. 2A and B), except for one Brazilian strain (CFBP 6378). Strain CFBP 6378 did not differ from strains originating from the Mascarene archipelago based on the ribosomal probe (rDNA-1), but was distinguishable by the hrp probe (hrp-5). RFLP haplotypes were consistent with AFLP data (Fig. 1).

PCR amplification with PXaa1 and NXaa1 primers. A PCR product of the expected size (697 bp) was observed for most, but not all, strains using PXaal primers. For all PXaa1-negative strains, no amplicon was obtained (expected size 447 bp) using internal NXaa1 primers. PCR-positive strains included all strains from the Mascarene archipelago, as well as strains of $X$. axonopodis pv. allii isolated in Japan. No amplicon was obtained for strains originating from Barbados. Four out of five Brazilian strains produced a positive reaction.
Pathogenicity tests. The pathogenicity of all tested strains, including strains isolated from onion seed, was confirmed by Koch postulates on the host species from which the strain originated. Moreover, all 28 strains, including AFLP group A and B strains originally isolated from diseased onion, leek, and garlic, were pathogenic to these three Allium species. In addition, large Xanthomonas population sizes $\left(\geq 10^{7} \mathrm{CFU}\right.$ lesion $\left.^{-1}\right)$ were recovered from at least 10 lesions per inoculated strain. On onion, typical lesions developed irrespective of the bacterial concentration used for inoculation. The length of the latent infection period ranged from 3 to 4 (with inocula of $10^{7} \mathrm{CFU} / \mathrm{ml}^{-1}$ ) to 7 to 11 days (with inocula of $10^{4} \mathrm{CFU} / \mathrm{ml}^{-1}$ ). On leek and garlic, lesions were observed primarily on plants inoculated with suspensions containing $10^{7} \mathrm{CFU} / \mathrm{ml}^{-1}$, suggesting a lower susceptibility of these two species. Because $X$. axonopodis pv. allii, together with secondary pathogens, induced a rapid decay of leaves on inoculated plants, it was not possible to reliably assess the aggressiveness of inoculated strains.

In planta multiplication in detached onion leaves. Based on nonlinear regression analysis of bacterial multiplication in planta over time, the Gompertz model was the most appropriate model. Daily multiplication rates $\left(\mathrm{r}^{*}\right)$ differed significantly among strains, and no obvious relationship with the host of origin was noted (Table 1). Similarly, the maximum population sizes derived from the Gompertz model (i.e., the asymptote, $K$ ) differed significantly among strains, by up to $0.7 \log$ unit (Table 1). However, $K$ may lack pertinence, as strains characterized by high multiplication rates tended to produce bacterial ooze on the agar media, which was not taken into account in the population size measurement.

\section{DISCUSSION}

AFLP fingerprints indicated that $X$. axonopodis pv. allii strains from the Mascarene archipelago were genetically different from those isolated in Barbados, Brazil, and Japan. Additional data (not shown) using strains of $X$. axonopodis pv. allii from Hawaii, mainland United States, South Africa, and Venezuela confirmed this result (Dice dissimilarity index $>0.3$ ). The marked difference between strains originating from the Mascarene archipelago and

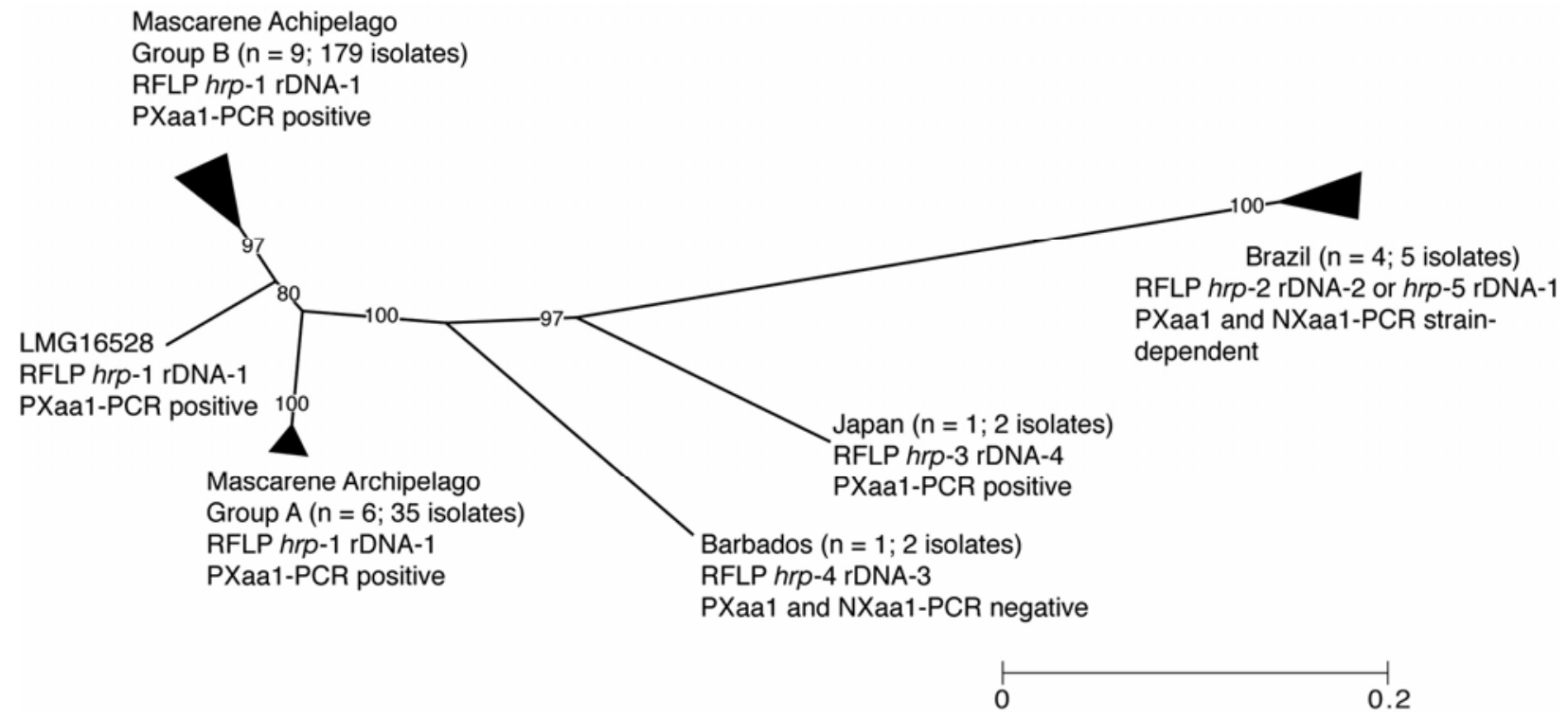

Fig. 1. Neighbor-joining tree derived from Dice dissimilarity indexes based on 183 amplified fragment length polymorphism (AFLP) markers showing the relationships between strains of Xanthomonas axonopodis pv. allii isolated in the Mascarene archipelago, Barbados, Brazil, and Japan (outgroups). Bootstrap values are shown. $\mathrm{n}$ is the number of haplotypes found within each group. Two main groups (designated A and B) were identified among strains isolated in the Mascarene archipelago. Group A contains strains producing pale yellow colonies isolated solely from onion. Group B contains strains producing bright yellow colonies originating from onion, leek, and garlic. A single strain from Réunion Island (LMG 16528) did not cluster within group A or B. The uniqueness of this strain allowed its efficient tracing in molecular epidemiological studies (17). 
strains from the other regions was confirmed by the RFLP (using a ribosomal and an hrp probe) and Biolog data (26). Our results are consistent with those by Gent et al. (13), which showed, using a logistic regression model, that differences in fatty acid and carbohydrate utilization profiles correlated fairly well with the geographic origin of the strains. Furthermore, our results confirm the large genetic diversity observed within a worldwide strain collection of $X$. axonopodis pv. allii using rep-PCR (13). Such a large intra-pathovar diversity also may explain why some strains of $X$. axonopodis pv. allii did not react with the PXaal and NXaa1 PCR primer pairs (17).

In contrast, on a regional scale, strains from Réunion Island share a high genetic similarity with those from Mauritius. Two groups of strains, referred herein as groups A and B, were isolated from outbreaks and contaminated seed. In addition, we report a presently unique epidemiological situation in Réunion Island, with concomitant major outbreaks on three Allium species (onion, leek, and garlic), which are associated with group B strains of $X$. axonopodis pv. allii. However, strains isolated from onion, leek, and garlic could not be distinguished based on AFLP data. Similarly, cross-inoculations indicated that all strains assayed were pathogenic to all three Allium species and that on onion multiplication rates of strains originating from leek and garlic were similar to that of strains originating from onion. Collectively, our data and a previous report (26) suggest a lack of pathological specialization of strains of $X$. axonopodis pv. allii from Réunion Island within the genus Allium. Spatial and climatic parameters probably play a key role in the concomitant outbreaks on onion, leek, and garlic. First, the three Allium crops share the same agricultural areas in both islands and secondly, the inoculum is likely to be shortly dispersed in these areas after the occurrence of wind-driven rains (28). The delayed epidemic situation observed on leek and garlic may be related to their lower susceptibility to $X$. axonopodis pv. allii, as determined by pathogenicity tests under controlled environmental conditions. However, AFLP data are not appropriate for deciphering micro-evolutionary events related to a very recent adaptation of strains on leek or garlic (33).

Groups A and B, which were genetically more similar to one another than to other groups, could not be clearly distinguished based on virulence and rates of multiplication in planta on onion. In contrast, these two groups could be clearly distinguished based

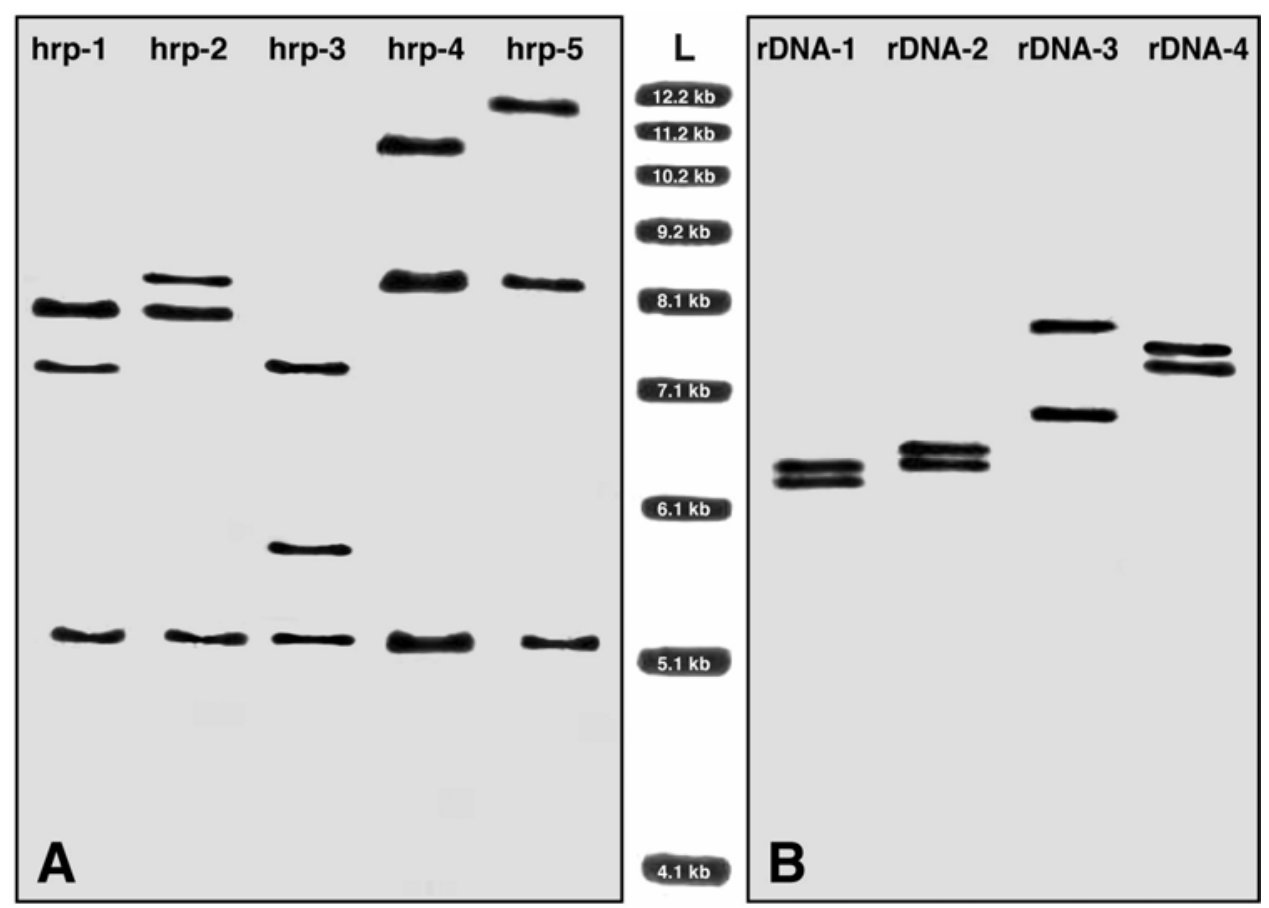

Fig. 2. Southern blots of digested DNAs from strains of Xanthomonas axonopodis pv. allii originating from the Mascarene archipelago, Barbados, Brazil, and Japan obtained with A, $h r p$ and B, rDNA probes. All strains from the Mascarene archipelago, Barbados, and Japan were identified as hrp-1 rDNA-1, hrp-4 rDNA3, and hrp-3 rDNA-4, respectively. Strains from Brazil were of two haplotypes, hrp-5 rDNA-1 (CFBP 6378) and hrp-2 rDNA-2 (other strains). L: 1-kb ladder.

TABLE 1. Nonlinear regression analysis using the Gompertz model and associated statistics for in planta multiplication of strains of Xanthomonas axonopodis pv. allii from Réunion Island in detached leaves of onion cv. Véronique

\begin{tabular}{|c|c|c|c|c|c|c|c|}
\hline Strain & Host of isolation & AFLP group & Rate $\left(\mathrm{r}^{*}\right)^{\mathrm{x}}$ & $\begin{array}{l}95 \% \text { confidence } \\
\text { interval of } r^{* y}\end{array}$ & $\begin{array}{l}\text { Maximum population } \\
\text { size }(K)\end{array}$ & $\begin{array}{l}\text { 95\% confidence interval } \\
\text { of } K^{\mathrm{y}}\end{array}$ & $R^{2 z}$ \\
\hline JQ632-1 & Onion & A & $0.632 \mathrm{~b}$ & $0.585-0.679$ & 8.901 & $8.724-9.084$ & 0.937 \\
\hline JR511-1 & Onion & A & $0.533 \mathrm{de}$ & $0.483-0.587$ & 9.500 & $9.206-9.833$ & 0.923 \\
\hline JX718-3 & Onion & B & $0.564 \mathrm{~d}$ & $0.520-0.605$ & 9.523 & $9.302-9.773$ & 0.944 \\
\hline LA187-47 & Onion & B & $0.605 a b c$ & $0.558-0.658$ & 9.226 & $8.999-9.469$ & 0.935 \\
\hline JX373-2 & Leek & B & $0.545 \mathrm{~d}$ & $0.510-0.583$ & 9.633 & $9.424-9.859$ & 0.947 \\
\hline LB239-18 & Leek & B & $0.568 \mathrm{~cd}$ & $0.528-0.611$ & 9.350 & $9.140-9.586$ & 0.940 \\
\hline
\end{tabular}

${ }^{\mathrm{x}} \mathrm{r}^{*}$ is the daily rate of bacterial multiplication and is expressed as $\log$ units leaf ${ }^{-1}$ day $^{-1}$. Different letters indicate significant differences based on a likelihood ratio test $(P=0.05)$.

${ }^{y}$ Bootstrap confidence intervals for the model parameters (1,000 iterations), as described in Huet et al. (16).

${ }^{\mathrm{z}}$ Adjusted coefficients of determination. 
on several characteristics including AFLP, differential utilization of three carbon sources (L-fucose, D-melibiose, and citric acid), and quantitative variations in xanthomonadin pigment. Xanthomonadins protect against photooxidative damage and play a role in epiphytic survival under natural, high light intensity $(18,23,24)$, which is the case in the tropical environment of the Mascarene archipelago. For instance, a reduction in xanthomonadin pigment production impaired the epiphytic survival of a $X$. campestris $\mathrm{pv}$. campestris mutant but did not reduce its in planta growth (23). Interestingly, group A (producing pale yellow colonies) and B (producing bright yellow colonies) strains were isolated from onion field outbreaks in Réunion Island at ratios close to $1: 1$ in the very first years following pathogen establishment. Less than a decade later, group A strains could no longer be isolated from field samples from the same areas (more than 500 isolation attempts in the main Allium production area from 2001 to 2005 yielded only group B strains), suggesting differences in fitness between group A and B strains. We can speculate that the low level of the group A strains xanthomonadin production may have reduced epiphytic fitness and led to the extinction of this group and the predominance of group B strains. However, several factors other than xanthomonadin pigments likely can influence epiphytic and epidemic fitness (29).

Early work on the BBO pathosystem suggested that onion seeds were the most likely sources of inocula for outbreaks recorded in Hawaii, although the causative bacterium was not detected from seed at that time due to the lack of efficient diagnostics tools (2). In Réunion Island BBO outbreaks were first observed on onion in 1993, 9 years after the first BBO observation from the neighboring island of Mauritius (S. Benimadhu, personal communication). Based on several molecular methods, strains associated with BBO in Réunion Island are highly related genetically to strains isolated from diseased onion from Mauritius Island. Although long distance movement of $X$. axonopodis pv. allii through diseased onion plants (the pathogen has never been detected from onion bulbs) or other pathways cannot be excluded, seed is the most probable pathway for introduction of $X$. axonopodis pv. allii in Réunion Island. This hypothesis was experimentally strengthened through the interception of $X$. axonopodis pv. allii-contaminated onion seed lots produced in Mauritius Island and imported into Réunion Island. Hence, the present study confirms previous suspicions that a seedborne inoculum of $X$. axonopodis pv. allii can become established in a virgin or already contaminated area (2). The importance of international movement of onion seed as a pathway for the worldwide emergence of BBO remains unknown, but may account for the global distribution of $X$. axonopodis pv. allii, introduction of $X$. axonopodis pv. allii into new onion-growing areas, and worldwide emergence of BBO. Our results suggest the need to develop certification schemes for onion seed against $X$. axonopodis pv. allii.

\section{ACKNOWLEDGMENTS}

We thank E. L. Civerolo for proofreading in English and manuscript review before submission, J. R. Neto, S. Benimadhu, S. Saumtally, and D. Stead for providing us with bacterial strains, and C. Boyer, K. Vital, and W. Grondin for skilled technical assistance. Odéadom, the European Union (FEOGA), Conseil Général de La Réunion, and CIRAD provided financial support.

\section{LITERATURE CITED}

1. Ah-You, N., Gagnevin, L., Chiroleu, F., Jouen, E., Neto, J. R., and Pruvost, O. 2007. Pathological variations within Xanthomonas campestris pv. mangiferaeindicae support its separation into three distinct pathovars that can be distinguished by amplified fragment length polymorphism. Phytopathology 97:1568-1577.

2. Alvarez, A. M., Buddenhagen, I. W., Buddenhagen, E. S., and Domen, H. Y. 1978. Bacterial blight of onion, a new disease caused by Xanthomonas sp. Phytopathology 68:1132-1136.
3. Ausubel, F. M., Brent, R., Kingston, R. E., Moore, D. D., Seidman, J. G., Smith, J. A., and Struhl, K. 1991. Current protocols in molecular biology. John Whiley \& Sons, New York.

4. Bochner, B. R. 1989. Sleuthing out bacterial identities. Nature 339:157158.

5. Bonas, U., Schulte, R., Fenselau, S., Minsavage, G. V., Staskawicz, B. J., and Stall, R. E. 1991. Isolation of a gene cluster from Xanthomonas campestris pv. vesicatoria that determines pathogenicity and the hypersensitive response on pepper and tomato. Mol. Plant-Microbe Interact. 4:81-88.

6. Da Silva, A. C., Ferro, J. A., Reinach, F. C., Farah, C. S., Furlan, L. R., Quaggio, R. B., Monteiro-Vitorello, C. B., Van Sluys, M. A., Almeida, N. F., Alves, L. M., Do Amaral, A. M., Bertolini, M. C., Camargo, L. E., Camarotte, G., Cannavan, F., Cardozo, J., Chambergo, F., Ciapina, L. P., Cicarelli, R. M., Coutinho, L. L., Cursino-Santos, J. R., El-Dorry, H., Faria, J. B., Ferreira, A. J., Ferreira, R. C., Ferro, M. I., Formighieri, E. F., Franco, M. C., Greggio, C. C., Gruber, A., Katsuyama, A. M., Kishi, L. T., Leite, R. P., Lemos, E. G., Lemos, M. V., Locali, E. C., Machado, M. A., Madeira, A. M., Martinez-Rossi, N. M., Martins, E. C., Meidanis, J., Menck, C. F., Miyaki, C. Y., Moon, D. H., Moreira, L. M., Novo, M. T., Okura, V. K., Oliveira, M. C., Oliveira, V. R., Pereira, H. A., Rossi, A., Sena, J. A., Silva, C., De Souza, R. F., Spinola, L. A., Takita, M. A., Tamura, R. E., Teixeira, E. C., Tezza, R. I., Trindade dos Santos, M., Truffi, D., Tsai, S. M., White, F. F., Setubal, J. C., and Kitajima, J. P. 2002. Comparison of the genomes of two Xanthomonas pathogens with differing host specificities. Nature 417:459-463.

7. Davidian, M., and Giltinan, D. M. 1995. Nonlinear models for repeated measurement data. Vol. 62. Monographs on Statistics and Applied Probability. Chapman \& Hall/CRC, Boca Raton, FL.

8. Duim, B., Godschalk, P. C. R., Van den Braak, N., Dingle, K. E., Dijkstra, J. R., Leyde, E., Van der Plas, J., Colles, F. M., Endtz, H. P., Wagenaar, J. A., Maiden, M. C. J., and Van Belkum, A. 2003. Molecular evidence for dissemination of unique Campylobacter jejuni clones in Curacao, Netherlands Antilles. J. Clin. Microbiol. 41:5593-5597.

9. Fearnley, C., On, S. L. W., Kokotovic, B., Manning, G., Cheasty, T., and Newell, D. G. 2005. Application of fluorescent amplified fragment length polymorphism for comparison of human and animal isolates of Yersinia enterocolitica. Appl. Environ. Microbiol. 71:4960-4965.

10. Gagnevin, L., Leach, J. E., and Pruvost, O. 1997. Genomic variability of the Xanthomonas pathovar mangiferaeindicae, agent of mango bacterial black spot. Appl. Environ. Microbiol. 63:246-253.

11. Gascuel, O. 1997. Concerning the NJ algorithm and its unweighted version UNJ. Pages 149-171 in: Mathematical Hierarchies and Biology. B. Mirkin, F. R. McMorris, F. Roberts, and A. Rzhetsky, eds. American Mathematical Society, Providence, RI.

12. Gent, D. H., Al-Saadi, A., Gabriel, D. W., Louws, F. J., Ishimaru, C. A., and Schwartz, H. F. 2005. Pathogenic and genetic relatedness among Xanthomonas axonopodis pv. allii and other pathovars of $X$. axonopodis. Phytopathology 95:918-925.

13. Gent, D. H., Schwartz, H. F., Ishimaru, C. A., Louws, F. J., Cramer, R. A., and Lawrence, C. B. 2004. Polyphasic characterization of Xanthomonas strains from onion. Phytopathology 94:184-195.

14. Hildebrand, D. C. 1971. Pectate and pectin gels for differentiation of Pseudomonas sp. and other bacterial plant pathogens. Phytopathology 61:1430-1436.

15. Huang, B., Heron, B. A., Gray, B. R., Eglezos, S., Bates, J. R., and Savill, J. 2004. A predominant and virulent Legionella pneumophila serogroup 1 strain detected in isolates from patients and water in Queensland, Australia, by an amplified fragment length polymorphism protocol and virulence gene-based PCR assays. J. Clin. Microbiol. 42:4164-4168.

16. Huet, S., Bouvier, A., Gruet, M. A., and Jolivet, E. 1996. Statistical Tools for Nonlinear Regression, Springer Series in Statistics. Springer-Verlag, Berlin, Heidelberg.

17. Humeau, L., Roumagnac, P., Picard, Y., Robène-Soustrade, I., Chiroleu, F., Gagnevin, L., and Pruvost, O. 2006. Quantitative and molecular epidemiology of bacterial blight of onion in seed production fields. Phytopathology 96:1345-1354.

18. Jenkins, C. L., and Starr, M. P. 1982. The brominated aryl-polyene (xanthomonadin) pigments of Xanthomonas juglandis protect against photobiological damage. Curr. Microbiol. 7:323-326.

19. Kadota, I., Uehara, K., Shinohara, H., and Nishiyama, K. 2000. Bacterial blight of Welsh onion: A new disease caused by Xanthomonas campestris pv. allii pv. nov. J. Gen. Plant Pathol. 66:310-315.

20. Lelliott, R. A., Billing, E., and Hayward, A. C. 1966. A determinative scheme for the fluorescent plant pathogenic pseudomonads. J. Appl. Bacteriol. 29:470-489.

21. Motiwala, A. S., Strother, M., Amonsin, A., Byrum, B., Naser, S. A., Stabel, J. R., Shulaw, W. P., Bannantine, J. P., Kapur, V., and Sreevatsan, S. 2003. Molecular epidemiology of Mycobacterium avium subsp. paratuberculosis: Evidence for limited strain diversity, strain sharing, 
and identification of unique targets for diagnosis. J. Clin. Microbiol. 41:2015-2026.

22. Nesme, X., Vaneechoutte, M., Orso, S., Hoste, B., and Swings, J. 1995. Diversity and genetic relatedness within genera Xanthomonas and Stenotrophomonas using restriction endonuclease site differences of PCRamplified 16S rRNA gene. Syst. Appl. Microbiol. 18:127-135.

23. Poplawsky, A. R., Urban, S. C., and Chun, W. 2000. Biological role of xanthomonadin pigments in Xanthomonas campestris pv. campestris. Appl. Environ. Microbiol. 66:5123-5127.

24. Rajagopal, L., Sundari, C. S., Balasubramanian, D., and Sonti, R. V. 1997. The bacterial pigment xanthomonadin offers protection against photodamage. FEBS Lett. 415:125-128.

25. Reche, M. P., Echeita, M. A., Garcia de los Rios, J. E., Usera, M. A., Jimenez, P. A., Rojas, A. M., Colas, J., and Rodriguez, I. 2003. Comparison of phenotypic and genotypic markers for characterization of an outbreak of Salmonella serotype Havana in captive raptors. J. Appl. Microbiol. 94:65-72.

26. Roumagnac, P., Gagnevin, L., Gardan, L., Sutra, L., Manceau, C., Dickstein, E. R., Jones, J. B., Rott, P., and Pruvost, O. 2004. Polyphasic characterization of xanthomonads isolated from onion, garlic and Welsh onion (Allium spp.) and their relatedness to different Xanthomonas species. Int. J. Syst. Evol. Microbiol. 54:15-24.

27. Roumagnac, P., Gagnevin, L., and Pruvost, O. 2000. Detection of Xan- thomonas sp., the causal agent of onion bacterial blight, in onion seeds using a newly developed semi-selective isolation medium. Eur. J. Plant Pathol. 106:867-877.

28. Roumagnac, P., Pruvost, O., Chiroleu, F., and Hughes, G. 2004. Spatial and temporal analyses of bacterial blight of onion caused by Xanthomonas axonopodis pv. allii. Phytopathology 94:138-146.

29. Rudolph, K. 1993. Infection of the plant by Xanthomonas. Pages 193-264 in: Xanthomonas. J. G. Swings and E. L. Civerolo, eds. Chapman \& Hall, London.

30. Schaad, N. W., ed. 1988. Laboratory Guide for Identification of Plant Pathogenic Bacteria. 2nd ed. The American Phytopathological Society, St. Paul, MN.

31. Siemer, B. L., Nielsen, E. M., and On, S. L. W. 2005. Identification and molecular epidemiology of Campylobacter coli isolates from human gastroenteritis, food, and animal sources by amplified fragment length polymorphism analysis and Penner serotyping. Appl. Environ. Microbiol. 71:1953-1958.

32. Vernière, C., Devaux, M., Pruvost, O., Couteau, A., and Luisetti, J. 1991. Studies on the biochemical and physiological variations among strains of Xanthomonas campestris pv. citri, the causal agent of citrus bacterial canker disease. Fruits 46:162-170.

33. Vuylsteke, M., Peleman, J. D., and Van Eijk, M. J. T. 2007. AFLP technology for DNA fingerprinting. Nature Prot. 2:1387-1398. 